\title{
Analysis on Temperature Distributions in Single Cell of Polymer Electrolyte Fuel Cell When Operated in High Temperature Range
}

\author{
Akira Nishimura ${ }^{1}$, Kotaro Osada ${ }^{1}$, Takuro Tsunoda ${ }^{1}$, Masato Yoshimura ${ }^{1}$, Masafumi Hirota ${ }^{1}$ and Eric $\mathrm{Hu}^{2}$ \\ 1. Division of Mechanical Engineering, Graduate School of Engineering, Mie University, Tsu-city, Mie 514-8507, Japan \\ 2. School of Mechanical Engineering, University of Adelaide, Adelaide, SA 5005, Australia
}

Received: June 08, 2016 / Accepted: June 21, 2016 / Published: August 31, 2016.

\begin{abstract}
This study is to understand the impact of operating condition, especially initial operation temperature $\left(T_{i n i}\right)$ which is set in high temperature range, on the temperature profile of the interface between PEM (polymer electrolyte membrane) and catalyst layer at the cathode (i.e., the reaction surface) in a single PEFC (polymer electrolyte fuel cell). A 1D multi-plate heat transfer model based on the temperature data of separator measured using thermograph in a power generation experiment was developed to evaluate the reaction surface temperature $\left(T_{\text {react }}\right)$. This study investigated the effects of flow rate, relative humidity and type of supply gas as well as $T_{i n i}$ on the temperature distribution on reaction surface. The results obtained in $\mathrm{O}_{2}$ supply case show that, the temperature rise at the segments near the outlet of cell decreases with increasing $T_{i n i}$ irrespective of relative humidity of supply gas (RH), while it is not seen in air supply case. Regarding the segments except near the outlet in $\mathrm{O}_{2}$ supply case, $T_{\text {react }}-T_{\text {ini }}$ increases with increasing $T_{\text {ini }}$ for $40 \% \mathrm{RH}$. The temperature distribution on reaction surface in $\mathrm{O}_{2}$ supply case is wider with increasing $T_{i n i}$ as well as decreasing RH, though that in air supply case is relatively even.
\end{abstract}

Key words: PEFC, heat transfer model, temperature distribution, high temperature operation.

\section{Introduction}

PEFC (polymer electrolyte fuel cell) is an attractive and clean power generation technology. However, there are some barriers preventing the widespread use of PEFCs among industries and homes worldwide. Some of such barriers are the reduction in the power generation performance and life span caused by the uneven distributions of a mass concentration and temperature inside a single cell of PEFC. Localized rise of temperature caused by local heat generation and poor gas diffusion blocked by the condensed water were thought to be reasons for the uneven temperature distribution [1-3].

The temperature distribution inside a single cell of

Corresponding author: Akira Nishimura, Ph.D., associate professor, research fields: heat transfer, fuel cell, photocatalyst and smart city.
PEFC is crucial to the performance of PEFC. Uneven temperature distribution could cause degradations of PEM (polymer electrolyte membrane) and catalyst layer. Localized temperature rise would cause thermal decomposition of PEM. The PEM could also be broken by thermal stress caused by the uneven temperature distribution $[2,4]$. Temperature distribution also influences the phase change of water. Water's behavior influences the performance of the PEM and gas flows in GDL (gas diffusion layer) and catalyst layer. Hence, it is important to understand the temperature distribution in single cell of PEFC in order to improve the power generation performance and realize the long life span, which is the aim of this study.

Ref. [5] reported the current density and temperature distributions in a PEFC under several operation conditions. The temperature distribution was measured by 10 very thin thermocouples located 
between GDL and catalyst layer at the cathode in this study. However, the width of the insulator covering thermocouple was one tenth of the gas channel width and many thermocouples were installed in the cell, resulting that the interference of thermocouples on mass, temperature and current density distributions was inevitable. Ref. [6] also measured the temperature distributions using the micro temperature sensor with a sensing area of $400 \mu \mathrm{m} \times 400 \mu \mathrm{m}$. Since this sensor was embedded in the cathode flow channel of separator, the temperature near the interface between PEM and catalyst layer at cathode, which is named as a reaction surface in the present paper, was not measured.

In another study conducted by Nishimura et al. [7], the temperature distributions on separator's back of single cell of PEFC were measured by thermograph. Without disturbing heat and mass transfer due to installation of sensor, the temperature distribution under power generation conditions was measured accurately. Based on the measuring data, the study tried to build an empirical model to predict the temperature distribution on reaction surface. According to a literature survey by the study, there was no previous study on estimating the temperature distribution on reaction surface from measured temperature data at separator's back. If the heat transfer model to predict the temperature distribution on reaction surface with the measured separator back's temperature would be developed, the temperature distribution on reaction surface could be easily estimated without difficult and complex temperature measurement.

In previous studies conducted by Nishimura et al. [8, 9], in order to estimate the temperature distribution inside single cell of PEFC, a 1D multi-plate heat transfer model using the temperature data of separator's back measured by thermograph under power generation was developed. Since the single cell of PEFC consists of some components having plate shapes such as PEM, catalyst layer, GDL and separator, the previous studies by Nishimura et al. [8, 9] proposed the heat transfer model assuming the heat transfer through multi-plates for these components of the cell. The reaction surface temperature $\left(T_{\text {react }}\right)$ was calculated using the heat transfer model. This is a new approach to identify the heat transfer mechanism in single cell of PEFC by means of the data measured by the thermograph and the model developed.

Comparing the results from the model with the other heat transfer models proposed in previous studies [10-12], there are differences among them, e.g., heat source. Ref. [10] developed a simplified 1D model, which considered for the heat transfer from PEM, catalyst layer, anode/cathode diffusion media and backing plate, based on Fourier's thermal conduction equation. This particular model [10] considered various heat sources such as Joule heating from PEM, entropic loss, activation and concentration overpotential, and Joule heating in catalyst layer. According to Ref. [10], the difference between $T_{\text {react }}$ and the backing plate (= separator) temperature was approximately $4.5{ }^{\circ} \mathrm{C}$ when the current density was $1.0 \mathrm{~A} / \mathrm{cm}^{2}$ and the backing plate end temperature was $80{ }^{\circ} \mathrm{C}$. Ref. [11] proposed another 1D model, which considered the heat transfer among MEA (membrane electrode assembly), catalyst layer, GDL, and carbon current collector by investigating various types of Nafion PEMs such as NER-212, Nafion 112, Nafion 115, and Nafion 117. In the model [11], the heat transfer through the in-plane direction of the cell was neglected and that toward the through-plane direction was investigated based on Fourier's thermal conduction equation. In addition, mole enthalpy of anode and cathode supply gas, vaporization enthalpy of water and reaction enthalpy were considered [11]. The difference between $T_{\text {react }}$ and the separator's back temperature was found to be about $4{ }^{\circ} \mathrm{C}$ under the condition that MEA temperature was $85^{\circ} \mathrm{C}$. Ref. [12] developed a nonisothermal 2D model that considered the heat transfer among PEM, catalyst layer and GDL, in which thermal conduction through the cell 
components was considered. Additionally, heat capacitance and heat generation/depletion parameters, including the thermodynamic irreversibility, heat generation by exothermic reaction, electron and proton transport resistance, and the phase change of water, were considered for Nafion PEMs. According to Ref. [12], the difference between $T_{\text {react }}$ and the temperature of current collector contacting the GDL at the cell voltage of $0.40 \mathrm{~V}$ was found to be $4{ }^{\circ} \mathrm{C}$ when using Nafion 115.

Although there were differences in terms of heat transfer calculations between the model developed by the present study and the other heat transfer models proposed in previous studies [10-12], the temperature gradients for the targeted regions under the similar operation conditions were almost the same [8]. Thus, it can be believed that, the heat transfer model proposed in the present study is reasonable.

The aim of the present paper is to predict the temperature distribution on the reaction surface under high temperature operation such as $90{ }^{\circ} \mathrm{C}$ condition, which is the target temperature for a stationary PEFC system during the duration from 2020 to 2030 according to NEDO road map [13] in Japan. If the PEFC system is operated at higher temperature than usual temperature, the following advantages can be obtained [14]: (1) an electrochemical reaction in catalyst layer is promoted, and (2) the tolerable concentration of $\mathrm{CO}$ which is by-product from a reforming of hydrocarbon fuel can be higher. However, the impact of hot spot on PEM becomes larger under high temperature operation condition. Therefore, it is more important to understand the temperature distribution on reaction surface under high temperature operation condition. This study also investigates the effects of initial operation temperature $\left(T_{i n i}\right)$, flow rate, relative humidity and type of supply gas on temperature distribution on reaction surface.

\section{Calculation Procedures}

\subsection{D Multi-plate Heat Transfer Model}

Fig. 1 illustrates the multi-plate single cell PEFC module used in this study. In the module, the separator's back is the opposite side of surface contacting GDL. The separator's back surface temperatures $T_{\text {surf, } c}$ and $T_{\text {surf }, a}$ were measured using thermograph.

The heat transfer across the module is assumed to be in 1D direction only. In the module, the cell is divided into a gas channel and a rib part. In Fig. 1, the

Anode separator back

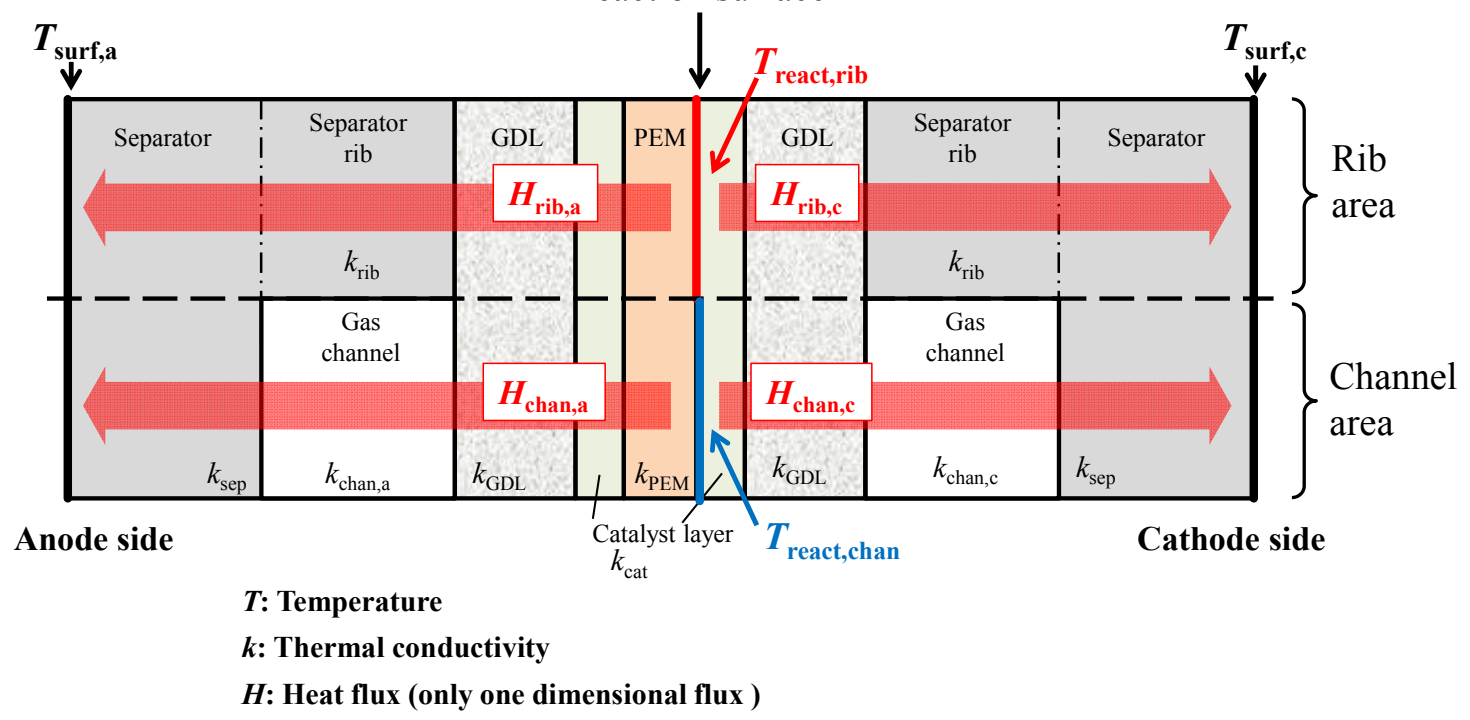

Fig. 1 1D multi-plate heat transfer module. 
upper and lower parts represent rib part and channel part, respectively. For both parts, the heat transfer was assumed to be in the through-plane direction. The reaction heat generated on reaction surface is transferred to the cathode and anode sides separately. Although the gas flowing through the gas channel from the inlet to the outlet of the cell carries away some heat, the amount of heat taken is less than $1 \%$ of the estimated reaction heat of approximately $20 \mathrm{~W}$ [8]. Therefore, the heat carried away by the gas flow was neglected in this model. Additionally, the mass flow rate of gas flowing through the gas channel is very small ranging from $10^{-8}$ to $10^{-6} \mathrm{~kg} / \mathrm{s}$, resulting that the thermal conduction of gas in the gas channel is assumed since the gas is thought to be static.

\subsection{Heat Generation Rate by Reaction}

The heat generation rate $H_{\text {react }}$ as a reaction product is calculated as the follows:

$$
H_{\text {react }}=E_{i}-W_{E}
$$

where, $E_{\mathrm{i}}$ is the ideal (total) energy generation rate by the water formation from $\mathrm{H}_{2}$ and $\mathrm{O}_{2}$ based on higher heating value except $T_{i n i}=100{ }^{\circ} \mathrm{C}$. The lower heating value is adopted for $T_{i n i}=100{ }^{\circ} \mathrm{C} . W_{E}$ is the electric work generated by PEFC. $E_{i}$ and $W_{E}$ are expressed as follows:

$$
\begin{gathered}
E_{\mathrm{i}}=m_{\mathrm{H}_{2}} \times q_{\mathrm{HHV}} \text { or } q_{\mathrm{LHV}} \\
W_{\mathrm{E}}=I \times V
\end{gathered}
$$

where, $I$ is the load current obtained by the experiment $(=20 \mathrm{~A})$. In this study, power generation data from a load current of $20 \mathrm{~A}\left(=0.80 \mathrm{~A} \cdot \mathrm{cm}^{-2}\right)$ except some conditions were used for the heat transfer modeling. $V$ is the voltage obtained by the experiment. $m_{H_{2}}$ is the molar flow rate of supplied $\mathrm{H}_{2}$, which is equal to the ideal reaction consumption rate of $\mathrm{H}_{2}$ required for the generation at $20 \mathrm{~A}$, i.e., the stoichiometric ratio of 1.0. Here, the stoichiometric ratio is the ratio of the feed amount of $\mathrm{H}_{2}$ or $\mathrm{O}_{2}$ to that required to generate a current of $20 \mathrm{~A}$. The flow rate of supply gas $\left(\mathrm{H}_{2}\right)$ at the stoichiometric ratio of 1.0 is defined as follows.

$$
m_{H_{2}}=I / n F
$$

where, $m_{\mathrm{H}_{2}}$ is the molar flow rate of supplied $\mathrm{H}_{2}$ $\left(\mathrm{mol} \cdot \mathrm{s}^{-1}\right) ; n$ is the valence of ion $\left(=2\right.$ for $\left.\mathrm{H}_{2}\right) ; F$ is the Faraday constant $\left(=96,500 \mathrm{C} \cdot \mathrm{mol}^{-1}\right) . \quad m_{O_{2}}$ which is the molar flow rate of supplied $\mathrm{O}_{2}\left(\mathrm{~mol} \cdot \mathrm{s}^{-1}\right)$ and is calculated as follows:

$$
\mathrm{H}_{2}+1 / 2 \mathrm{O}_{2}=\mathrm{H}_{2} \mathrm{O}
$$

The actual stoichiometric ratio of supply gas was confirmed, using the mass flow controller installed at the inlet of the single cell and the mass flow mater installed at the outlet of the cell in the power generation experiment [7].

\subsection{Heat-Balance Equations for Calculating Reaction Surface Temperature}

The heats transferred in the model proposed are expressed as Eqs. (6)-(10):

$$
\begin{aligned}
& H_{\text {rib,c }}=K_{\text {rib, }, c} A\left(T_{\text {react, rib }}-T_{\text {surf }, c}\right) / 2 \\
& H_{\text {chan }, c}=K_{\text {chan, }, ~} A\left(T_{\text {react, chan }}-T_{\text {surf }, c}\right) / 2 \\
& H_{\text {rib, } a}=K_{\text {rib, a }} A\left(T_{\text {react, rib }}-T_{\text {surf }, a}\right) / 2 \\
& H_{\text {chan }, a}=K_{\text {chan , a }} A\left(T_{\text {react, chan }}-T_{\text {surf }, a}\right) / 2 \\
& H_{\text {react }}=H_{\text {rib }, c}+H_{\text {chan }, c}+H_{\text {rib }, a}+H_{\text {chan }, a}
\end{aligned}
$$

where, $H_{r i b, c}$ is the heat flux to cathode side under rib (W); $K_{r i b, c}$ is the overall heat transfer coefficient for cathode side under $\mathrm{rib}\left(\mathrm{W} \cdot \mathrm{m}^{-2} \cdot \mathrm{K}^{-1}\right) ; A$ is the heat transfer area which is the active area of MEA, i.e., power-generation area $\left(=0.0025 \mathrm{~m}^{2}\right) ; T_{\text {react, } \text { rib }}$ is the reaction surface temperature under rib $\left(\mathrm{K}\right.$ or $\left.{ }^{\circ} \mathrm{C}\right) ; T_{\text {surf }}$, $c$ is the separator's back surface temperature at cathode $\left(\mathrm{K}\right.$ or $\left.{ }^{\circ} \mathrm{C}\right) ; H_{\text {chan }, c}$ is the heat flux to cathode side under channel $(\mathrm{W}) ; K_{\text {chan }, c}$ is the overall heat transfer coefficient for cathode side under channel $\left(\mathrm{W} \cdot \mathrm{m}^{-2} \cdot \mathrm{K}^{-1}\right) ; \quad T_{\text {react, }}$ chan is the reaction surface temperature under channel $\left(\mathrm{K}\right.$ or $\left.{ }^{\circ} \mathrm{C}\right) ; H_{r i b, a}$ is the heat flux to anode side under rib (W); $K_{r i b, a}$ is the overall heat transfer coefficient for anode side under rib $\left(\mathrm{W} \cdot \mathrm{m}^{-2} \cdot \mathrm{K}^{-1}\right) ; T_{\text {surf, } a}$ is the separator's back temperature at anode $\left(\mathrm{K}\right.$ or $\left.{ }^{\circ} \mathrm{C}\right) ; H_{\text {chan, } a}$ is the heat flux to anode side under channel (W); $K_{\text {chan, } a}$ is the overall heat transfer coefficient for anode side under channel $\left(\mathrm{W} \cdot \mathrm{m}^{-2} \cdot \mathrm{K}^{-1}\right) . K_{r i b, c}, K_{\text {chan, }}, K_{r i b, a}$ and $K_{\text {chan, } a}$ are 


\section{Analysis on Temperature Distributions in Single Cell of Polymer Electrolyte Fuel Cell When Operated in High Temperature Range}

defined as follows:

$$
\begin{aligned}
1 / K_{\text {rib }, c}= & \delta_{\text {cat }} / k_{\text {cat }}+\delta_{G D L} / k_{G D L}+\delta_{\text {rib }} / k_{\text {rib }}+\delta_{\text {sep }} / k_{\text {sep }} \\
1 / K_{\text {chan }, c}= & \delta_{\text {cat }} / k_{\text {cat }}+\delta_{G D L} / k_{G D L}+\delta_{\text {chan }} / k_{\text {chan }, c} \\
& +\delta_{\text {sep }} / k_{\text {sep }} \\
1 / K_{\text {rib }, a}= & \delta_{P E M} / k_{P E M}+\delta_{\text {cat }} / k_{\text {cat }}+\delta_{G D L} / k_{G D L} \\
& +\delta_{\text {rib }} / k_{\text {rib }}+\delta_{\text {sep }} / k_{\text {sep }} \\
1 / K_{\text {chan }, a}= & \delta_{P E M} / k_{P E M}+\delta_{\text {cat }} / k_{\text {cat }}+\delta_{G D L} / k_{G D L} \\
& +\delta_{\text {chan }} / k_{\text {chan }, a}+\delta_{\text {sep }} / k_{\text {sep }}
\end{aligned}
$$

where, $\delta_{\text {cat }}$ is the thickness of the catalyst layer $(\mathrm{m})$; $k_{\text {cat }}$ is the thermal conductivity of the catalyst layer $\left(\mathrm{W} \cdot \mathrm{m}^{-1} \cdot \mathrm{K}^{-1}\right) ; \delta_{G D L}$ is the thickness of GDL $(\mathrm{m}) ; k_{G D L}$ is the thermal conductivity of GDL $\left(\mathrm{W} \cdot \mathrm{m}^{-1} \cdot \mathrm{K}^{-1}\right) ; \delta_{r i b}$ is the thickness of the separator rib $(\mathrm{m}) ; k_{r i b}$ is the thermal conductivity of the separator $\mathrm{rib}\left(\mathrm{W} \cdot \mathrm{m}^{-1} \cdot \mathrm{K}^{-1}\right)$; $\delta_{\text {sep }}$ is the thickness of the separator excluding rib part (m); $k_{\text {sep }}$ is the thermal conductivity of the separator excluding rib part $\left(\mathrm{W} \cdot \mathrm{m}^{-1} \cdot \mathrm{K}^{-1}\right) ; \delta_{\text {chan }}$ is the thickness of the channel of separator (m); $k_{\text {chan }}$ is the thermal conductivity of the mixture gas in the channel of separator $\left(\mathrm{W} \cdot \mathrm{m}^{-1} \cdot \mathrm{K}^{-1}\right) ; \delta_{P E M}$ is the thickness of PEM; $k_{P E M}$ is the thermal conductivity of PEM.

Table 1 lists the specification of cell components used in the model. The materials of PEM, catalyst layer, GDL and separator are Nafion 115, compound of platinum and carbon, carbon paper and carbon graphite, respectively. The thickness values listed here are the same as those of the components used by previous studies $[7,15,16]$.

In Table 1, the effective thermal conductivities of porous media $k$, are the values of the cell components used in the present experiment and in Refs. [7, 10]. Since the effective thermal conductivities given in Table 1 are obtained when the cell component pores are filled with air at room temperature, the corrected effective thermal conductivities are calculated for the cell component pores filled with $\mathrm{H}_{2}$ or $\mathrm{O}_{2}$ at $80{ }^{\circ} \mathrm{C}$ or $90{ }^{\circ} \mathrm{C}$ or $100{ }^{\circ} \mathrm{C}$, which were the $T_{i n i}$ value assumed in this study. In this calculation, the thermal conductivities of each gas are from The Japan Society of Mechanical Engineers [17].

In order to solve Eqs. (6)-(9), the temperatures measured using the thermograph were substituted into these equations as $T_{\text {surf, } c}$ and $T_{\text {surf, } a}$. The operation conditions used for power generation in order to measure temperatures with thermograph are given in Table 2. Analysis using 1D multi-plate heat transfer is carried out by means of the data obtained under these conditions. The experimental procedure for measuring temperature during power generation has been explained in Ref. [7].

In order to use the temperature data measured by thermograph in 1D multi-plate heat transfer model, the image of in-plane temperature distribution is divided into segments of $10 \mathrm{~mm} \times 10 \mathrm{~mm}$ each, as shown in Fig. 2. Although the power generation area is $50 \mathrm{~mm}$

\begin{tabular}{|c|c|c|c|c|}
\hline Parts & Size & Characteristics & Porosity (-) & $\begin{array}{l}\text { Effective thermal } \\
\text { conductivity } \\
\left(\mathrm{W} \cdot \mathrm{m}^{-1} \cdot \mathrm{K}^{-1}\right)\end{array}$ \\
\hline $\begin{array}{l}\text { PEM (polymer } \\
\text { electrolyte membrane) }\end{array}$ & $50.0 \mathrm{~mm} \times 50.0 \mathrm{~mm} \times 0.13 \mathrm{~mm}$ & $\begin{array}{l}\text { Nafion } 115 \text { (produced } \\
\text { by Du Pont Corp.) }\end{array}$ & 0.15 & 0.195 \\
\hline Catalyst layer & $\begin{array}{l}50.0 \mathrm{~mm} \times 50.0 \mathrm{~mm} \times 0.01 \mathrm{~mm} \\
\text { (attached with PEM) }\end{array}$ & $\begin{array}{l}\mathrm{Pt} / \mathrm{C} \\
(20 \mathrm{wt} \% \mathrm{Pt} \text { loading })\end{array}$ & 0.78 & 0.27 \\
\hline $\begin{array}{l}\text { GDL (gas diffusion } \\
\text { layer) }\end{array}$ & $50.0 \mathrm{~mm} \times 50.0 \mathrm{~mm} \times 0.17 \mathrm{~mm}$ & $\begin{array}{l}\text { Carbon paper } \\
\text { (TGP-H- } 060 \text { produced }( \\
\text { by Toray Corp.) }\end{array}$ & 0.78 & 1.7 \\
\hline Separator & $\begin{array}{l}75.4 \mathrm{~mm} \times 75.4 \mathrm{~mm} \times 2.00 \mathrm{~mm} \\
\text { (thickness of rib part: } 1.00 \mathrm{~mm} \text { ) } \\
\text { (Gas supply area: } 50.0 \mathrm{~mm} \times 50.0 \mathrm{~mm} \text { ) }\end{array}$ & $\begin{array}{l}\text { Carbon graphite, } \\
\text { serpentine }\end{array}$ & 0.28 & 25 \\
\hline
\end{tabular}
$\times 50 \mathrm{~mm}$, the observation area is set to be $40 \mathrm{~mm} \times 50$ $\mathrm{mm}$ to prevent a gas leak through observation window in the experiments. The gas channel width and the rib width of investigated separator are $10 \mathrm{~mm}$ and the number of gas channel is 5 . The segment includes the

Table 1 Specification of cell components. 
Table 2 Operating conditions of power generation for temperature measurement by thermograph.

\begin{tabular}{|c|c|c|}
\hline $\begin{array}{l}\text { Initial temperature of cell }\left({ }^{\circ} \mathrm{C}\right) \\
\text { Load current of cell }(\mathrm{A}) \\
\left(\text { Current density of cell }\left(\mathrm{A} / \mathrm{cm}^{2}\right)\right)\end{array}$ & $\begin{array}{l}80,90,100 \\
20^{*} \\
(0.80) \\
\end{array}$ & \\
\hline \multicolumn{3}{|c|}{ Supply gas condition } \\
\hline & Anode & Cathode \\
\hline Gas type & $\mathrm{H}_{2}$ & $\mathrm{O}_{2}$ or Air \\
\hline Temperature of supply gas at inlet $\left({ }^{\circ} \mathrm{C}\right)$ & $80,90,100$ & $80,90,100$ \\
\hline Relative humidity of supply gas (\% RH) & $40,60,80$ & $40,60,80$ \\
\hline Pressure of supply gas at inlet (absolute) (MPa) & 0.4 & 0.4 \\
\hline Flow rate of supply gas at inlet (NL/min) (Stoichiometric ratio (-)) & $\begin{array}{l}0.210(1.5), \\
0.280(2.0), \\
0.420(3.0)\end{array}$ & $\begin{array}{l}0.105(1.5), \\
0.140(2.0), \\
0.210(3.0)\end{array}$ \\
\hline
\end{tabular}

* including some exception condition as shown in Table 3.

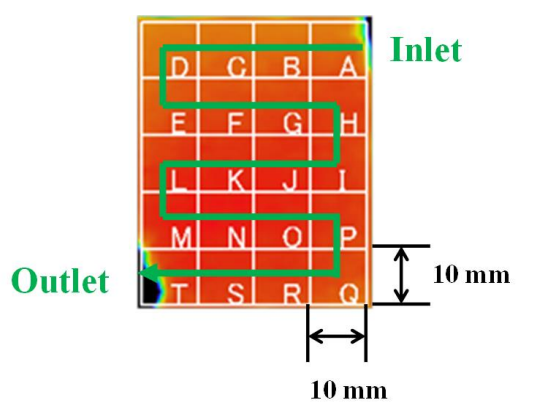

Fig. 2 Segment display of in-plane temperature distribution measured by thermograph.

area consisting of five pairs of rib and gas channel. The average temperature in each segment at anode and cathode was used for the separator's back temperature in 1D multi-plate heat transfer model. The segment is named $\mathrm{A}$ to $\mathrm{T}$ along the gas flow direction as shown in Fig. 2. Regarding segments $\mathrm{A}$ and $\mathrm{T}$, the insulators covering the gas pipes interfere with the thermograph measurement in some area of the segment as it can be seen in Fig. 2. In this study, the effective temperature of segments $\mathrm{A}$ and $\mathrm{T}$ were obtained by removing the temperature data that were interfered by the insulator from the total temperature data in each segment. In the heat transfer analysis, it was assumed that $T_{\text {surf }, c}$ on the rib side was equal to $T_{\text {surf }, c}$ on the channel side as well as $T_{\text {surf, } a}$ because the difference between them could not be recognized by the measured data.

By the comparison of temperature distribution between in-plane and through-plane, the difference between $T_{\text {react, rib }}$ and $T_{\text {react, chan }}$ was found to be small, i.e., less than $1{ }^{\circ} \mathrm{C}[11,12,18]$, while the temperature difference between reaction surface and separator's back was approximately $1-7^{\circ} \mathrm{C}$ in the present study. Consequently, it is believed that the heat flow in the through-plane direction dominates the heat transfer in the cell.

Considering the above described assumptions and Eqs. (6)-(14), the reaction surface temperature $T_{\text {react }}$ is expressed as follows:

$$
\begin{gathered}
T_{\text {react }}=T_{\text {react, rib }}=T_{\text {react, chan }} \\
=\left\{2 H_{\text {react }} / A+\left(K_{\text {rib }, c}+K_{\text {chan }, c}\right) / T_{\text {surf }, c}+\left(K_{\text {rib }, a}+\right.\right. \\
\left.\left.K_{\text {chan }, a}\right) T_{\text {surf }, a}\right\} /\left(K_{\text {rib }, c}+K_{\text {chan }, c}+K_{\text {rib }, a}+K_{\text {chan }, a}\right)
\end{gathered}
$$

\section{Results and Discussion}

\subsection{Temperature Distribution Calculated by $1 D$ Multi-plate Heat Transfer Model}

Fig. 3 shows the effect of $T_{\text {ini }}$ on temperature distribution on reaction surface simulated by the $1 \mathrm{D}$ model when the relative humidity of supply gas was $80 \% \mathrm{RH}$ and the stoichiometric ratio of supply gases were $1.5,2.0$ and 3.0, respectively. It can be seen that the effect of flow rate of supply gas on the temperature distribution was not significant.

Fig. 3 shows that the reaction surface temperature rise, i.e., $T_{\text {react }}-T_{\text {ini }}$, at the segments from $\mathrm{Q}$ to $\mathrm{T}$ which are near the outlet of cell decreases with the increasing of $T_{i n i}$. The PEM was dehydrated with gas flowing through gas channel, especially near the outlet of cell due to accumulation of heat generated by power generation, which proceeded more at higher 


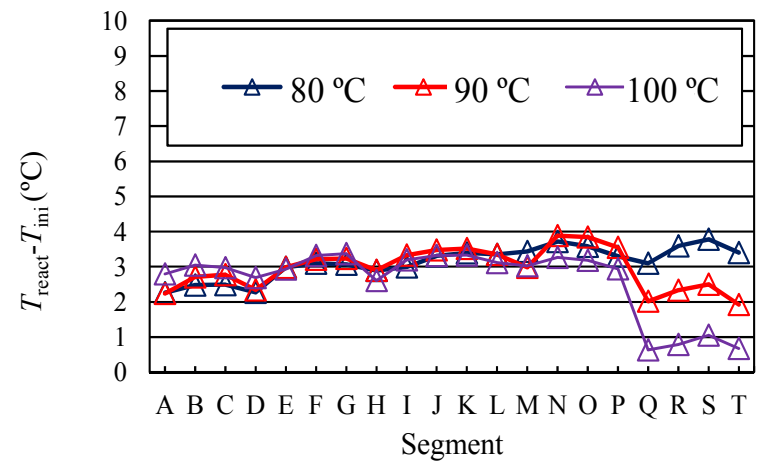

(a) Stoichiometric ratio: 1.5

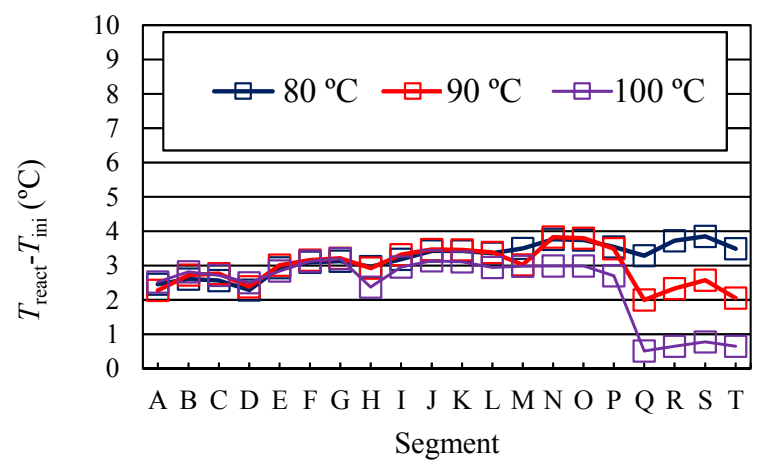

(b) Stoichiometric ratio: 2.0

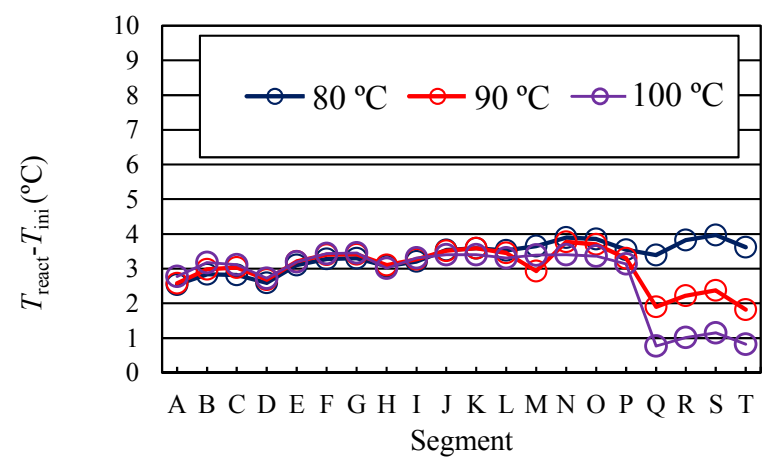

(c) Stoichiometric ratio: 3.0

Fig. 3 Effect of $T_{\text {ini }}$ on $T_{\text {react }}$ calculated by the $1 D$ model for relative humidity of supply gas of $80 \%$ RH.

$T_{\text {ini }}$. Consequently, the temperature drops near the outlet due to degradation of electrochemical reaction performance.

However, it is also seen that the difference of $T_{\text {react }}$ - $T_{i n i}$ among various $T_{i n i}$ is small at every segment except the segments near the outlet. From the voltages obtained by power generation experiments shown in Table 3, the difference of power generation performance among various $T_{i n i}$ is a small due to well humidification, especially $T_{i n i}$ of $80^{\circ} \mathrm{C}$ and $90^{\circ} \mathrm{C}$, resulting that the difference of $T_{\text {react }}-T_{\text {ini }}$ is small.

In addition, it is found that $T_{\text {react }}-T_{\text {ini }}$ drops at the segments $\mathrm{H}$ and $\mathrm{M}$ irrespective of $T_{i n i}$. Since these segments are located at the turn-round parts of gas channels as shown in Fig. 2, the water droplets are easy to remain in the case of serpentine gas channel [19] used in the present experiment and the previous study [7]. The gas diffusion toward catalyst layer is disrupted in these segments, resulting that the electrochemical reaction is not occurred well. Thus, $T_{\text {react }}$ drops in these segments. Therefore, it is important to remove the water from the turn-round parts of gas channel in order to achieve the even in-plane temperature distribution on reaction surface. As to the segment $\mathrm{D}$, it is also seen that $T_{\text {react }}-T_{\text {ini }}$ drops. Since it is the inlet of the opposite anode side, resulting that the cell is cooled by the gas which is colder than the cell heated by reaction heat.

Fig. 4 shows the effect of $T_{i n i}$ on temperature distribution on reaction surface calculated by the 1D model in each segment in the cell for relative humidity of supply gas was $60 \% \mathrm{RH}$. The stoichiometric ratios of the supply gases were $1.5,2.0$ and 3.0. It can be seen that the effect of flow rate of supply gas on the temperature distribution was not significant.

According to Fig. 4, the similar (to Fig. 3) results can be seen, which is that $T_{\text {react }}-T_{i n i}$ at the segments from $\mathrm{Q}$ to $\mathrm{T}$ decreases with the increasing of $T_{i n i}$. In addition, the difference of $T_{\text {react }}-T_{i n i}$ among various $T_{i n i}$ is small at every segment except the segments near the outlet. Though $T_{\text {reat }}-T_{\text {ini }}$ drop is observed at the segments $\mathrm{D}$ and $\mathrm{H}$, it can not be seen at the segment M, which is different to the results in Fig. 3. Due to accumulation of heat generated, the temperature of gas flow through gas channel becomes higher and higher in flow direction, thus the liquid water is harder to form especially when the relative humidity is lower. Consequently, it is not observed that $T_{\text {react }}-T_{\text {ini }}$ drops at the segment $\mathrm{M}$ (in Fig. 4).

Fig. 5 shows the effect of $T_{i n i}$ on temperature distribution on reaction surface calculated by the 1D 
Table 3 Comparison of power generation performance obtained by power generation experiment among different operating conditions.

\begin{tabular}{|c|c|c|c|c|}
\hline Cathode gas & $T_{i n i}\left({ }^{\circ} \mathrm{C}\right)$ & $\begin{array}{l}\text { Relative humidity of } \\
\text { supply gas }(\% \mathrm{RH})\end{array}$ & Flow rate of supply gas (Stoichiometric ratio) & Current (A), Voltage (V) \\
\hline & & & 1.5 & $20.0,0.43$ \\
\hline & & 40 & 2.0 & $20.0,0.41$ \\
\hline & & & 3.0 & $20.0,0.36$ \\
\hline & & & 1.5 & $20.0,0.50$ \\
\hline & 80 & 60 & 2.0 & $20.0,0.51$ \\
\hline & & & 3.0 & $20.0,0.49$ \\
\hline & & & 1.5 & $20.0,0.56$ \\
\hline & & 80 & 2.0 & $20.0,0.55$ \\
\hline & & & 3.0 & $20.0,0.53$ \\
\hline & & & 1.5 & $20.0,0.38$ \\
\hline & & 40 & 2.0 & $20.0,0.33$ \\
\hline & & & 3.0 & $20.0,0.26$ \\
\hline & & & 1.5 & $20.0,0.46$ \\
\hline \multirow[t]{18}{*}{$\mathrm{O}_{2}$} & 90 & 60 & 2.0 & $20.0,0.46$ \\
\hline & & & 3.0 & $20.0,0.45$ \\
\hline & & & 1.5 & $20.0,0.52$ \\
\hline & & 80 & 2.0 & $20.0,0.52$ \\
\hline & & & 3.0 & $20.0,0.52$ \\
\hline & & & 1.5 & $19.0,0.09$ \\
\hline & & 40 & 2.0 & $19.0,0.08$ \\
\hline & & & 3.0 & $19.0,0.09$ \\
\hline & & & 1.5 & $20.0,0.37$ \\
\hline & 100 & 60 & 2.0 & $20.0,0.37$ \\
\hline & & & 3.0 & $20.0,0.36$ \\
\hline & & & 1.5 & $20.0,0.40$ \\
\hline & & 80 & 2.0 & $20.0,0.42$ \\
\hline & & & 3.0 & $20.0,0.41$ \\
\hline & & & 1.5 & $18.5,0.22$ \\
\hline & 80 & 80 & 2.0 & $19.0,0.24$ \\
\hline & & & 3.0 & $20.0,0.26$ \\
\hline & & & 1.5 & $18.0,0.21$ \\
\hline \multirow[t]{5}{*}{ Air } & 90 & 80 & 2.0 & $19.0,0.21$ \\
\hline & & & 3.0 & $20.0,0.23$ \\
\hline & & & 1.5 & - \\
\hline & 100 & 80 & 2.0 & $19.0,0.24$ \\
\hline & & & 3.0 & $20.0,0.26$ \\
\hline
\end{tabular}

model in each segment in the cell for relative humidity of supply gas of $40 \% \mathrm{RH}$. The stoichiometric ratios of the supply gases were 1.5, 2.0 and 3.0. Though the effect of flow rate of supply gas on temperature distribution has been investigated, there is a few impact.

It can be seen from Fig. 5 that $T_{\text {react }}-T_{\text {ini }}$ at the segments from $\mathrm{Q}$ to $\mathrm{T}$ which is near the outlet of cell decreases with the increasing of $T_{i n i}$. The reason of this is thought to be the same in the case of $80 \% \mathrm{RH}$ and $60 \%$ RH. However, compared to Figs. 3 and 4, the different tendency is observed at the segments except the positions near the outlet. It can be seen that $T_{\text {react }}-T_{\text {ini }}$ increases with the increasing of $T_{\text {ini }}$. A water generated by electrochemical reaction is a little due to low relative humidity condition. Additionally, 

Fuel Cell When Operated in High Temperature Range

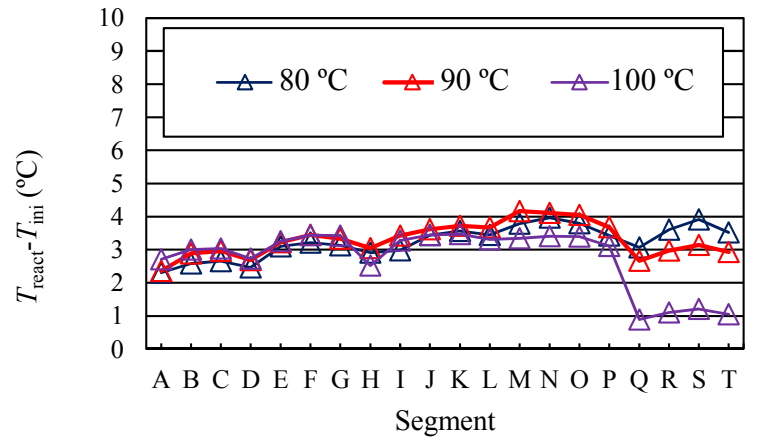

(a) Stoichiometric ratio: 1.5

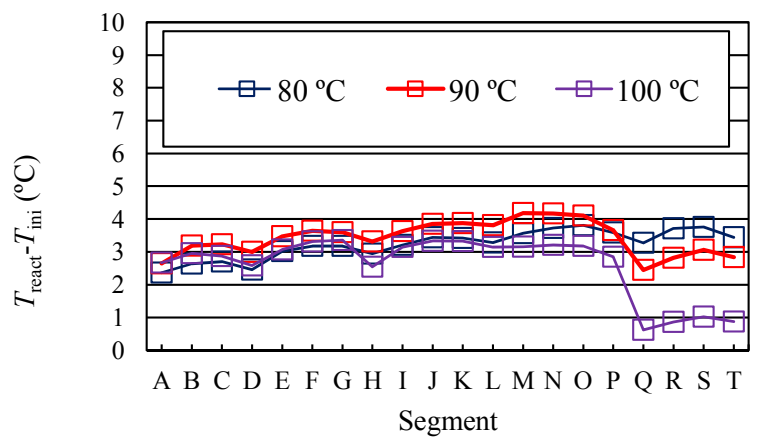

(b) Stoichiometric ratio: 2.0

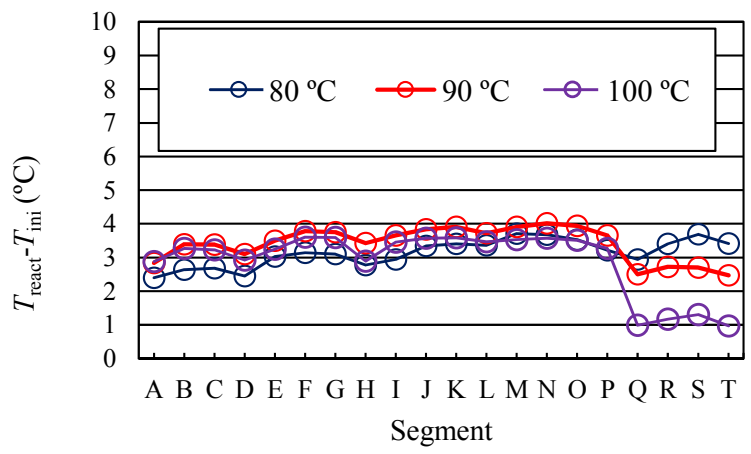

(c) Stoichiometric ratio: 3.0

Fig. 4 Effect of $\boldsymbol{T}_{\text {ini }}$ on $\boldsymbol{T}_{\text {react }}$ calculated by the 1D model for relative humidity of supply gas of $60 \%$ RH.

PEM is dehydrated more at higher $T_{i n i}$, which causes a degradation of proton conductivity of PEM. Since the power generation decreases, the energy which can not be converted to electricity but heat increases. The electrochemical reaction itself is carried out near the inlet of cell since the amount of supply gas is adequate, which provides the heat converted by electrochemical reaction, i.e., temperature rise. On the other hand, the electrochemical reaction performance itself is very poor near the outlet of cell due to huge dehydration by accumulated heat of gas flowing

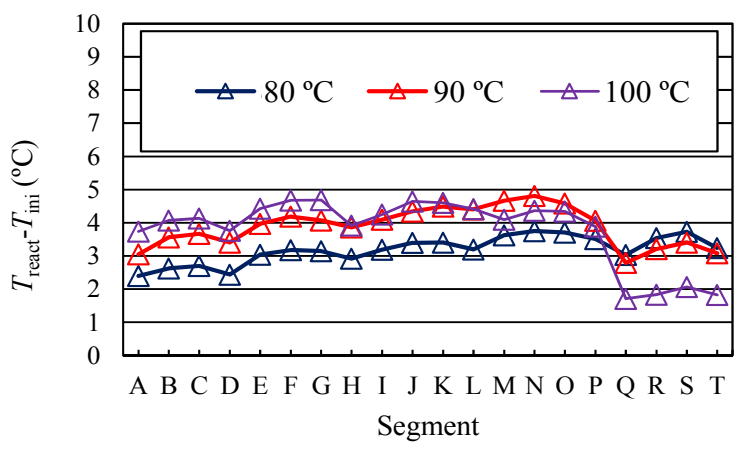

(a) Stoichiometric ratio: 1.5

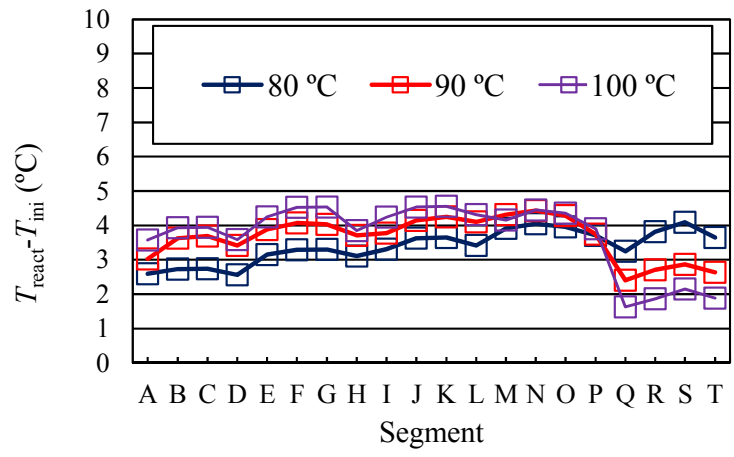

(b) Stoichiometric ratio: 2.0

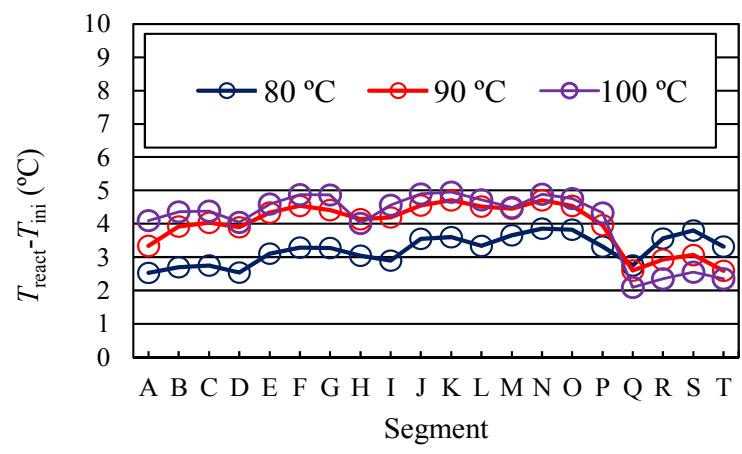

(c) Stoichiometric ratio: 3.0

Fig. 5 Effect of $\boldsymbol{T}_{\text {ini }}$ on $\boldsymbol{T}_{\text {react }}$ calculated by the 1D model for relative humidity of supply gas of $40 \% \mathrm{RH}$.

through gas channel from the inlet of cell, which leads to temperature drop. It is believed that this is the reason for that the temperature rise from $T_{i n i}$ becomes high or not.

Fig. 6 shows the effect of cathode gas type on the temperature distribution on reaction surface calculated by the 1D model in each segment in the cell for relative humidity of supply gas of $80 \% \mathrm{RH}$. The results obtained at the stoichiometric ratios of the supply gases of 2.0 and 3.0 were shown since the power generation was not carried out at the 


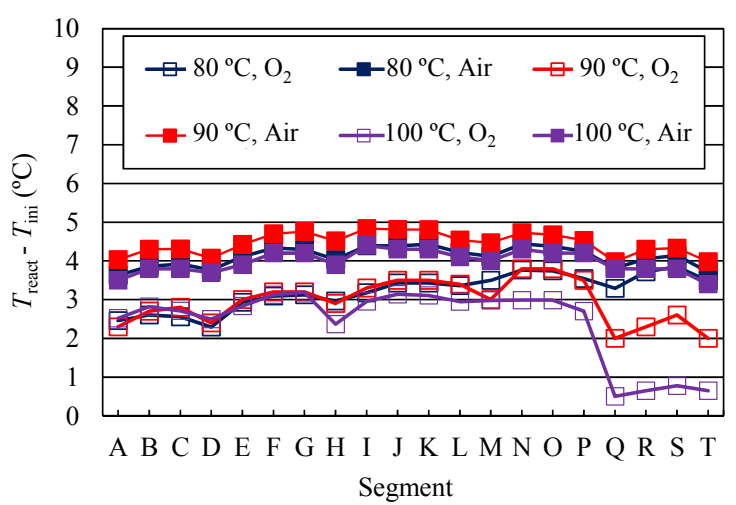

(a) Stoichiometric ratio: 2.0

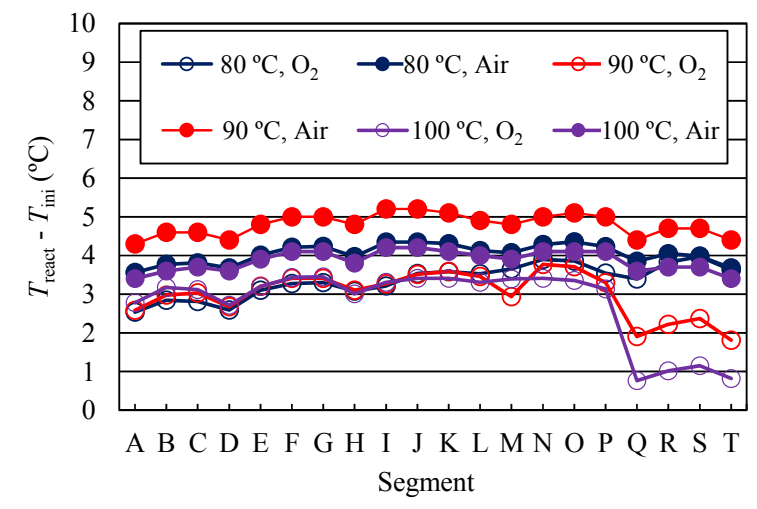

(b) Stoichiometric ratio: 3.0

Fig. 6 Effect of cathode gas type on $\boldsymbol{T}_{\text {react }}$ calculated by the $1 D$ model for relative humidity of supply gas of $80 \% \mathrm{RH}$.

stoichiometric ratio of 1.5 and $T_{\text {ini }}$ of $100{ }^{\circ} \mathrm{C}$ in air supply case. As shown in Table 3, the power generation was conducted at the current of $19.0 \mathrm{~A}$ for the stoichiometric ratio of 2.0 irrespective of $T_{\text {ini }}$ since the power generation was not carried out at the current of $20 \mathrm{~A}$. Therefore, $E_{i}$ and $W_{E}$ were calculated on the basis of current of $19.0 \mathrm{~A}$ in this case.

According to Fig. 6, it is seen that $T_{\text {react }}-T_{\text {ini }}$ in air supply case is higher than that in $\mathrm{O}_{2}$ supply case irrespective of $T_{i n i}$ and flow rate of supply gas. Since the power generation performance in air supply case is worse than that in $\mathrm{O}_{2}$ supply case as shown in Table 3, $H_{\text {react }}$ in air supply case is higher than that in $\mathrm{O}_{2}$ supply case according to Eq. (1), resulting in higher $T_{\text {react }}-T_{\text {ini }}$. It can be also seen that $T_{\text {react }}-T_{\text {ini }}$ at the segments from $\mathrm{Q}$ to $\mathrm{T}$ does not decrease in air supply case, which is different compared to $\mathrm{O}_{2}$ supply case. Since the flow rate of supply gas in air supply case is larger than that in $\mathrm{O}_{2}$ supply case due to $\mathrm{N}_{2}$ addition, it is believed that the reaction surface is cooled by the excess gas. Therefore, the accumulation of heat generated by power generation near the outlet of cell is not occurred, resulting that PEM is not dehydrated well and the temperature drop near the outlet of cell is not observed.

From the investigation by this study, the temperature distribution on reaction surface in $\mathrm{O}_{2}$ supply case is wider with the increasing of $T_{i n i}$ as well as the decreasing of relative humidity of supply gas, while the temperature distribution on reaction surface in air supply case is relatively even. However, $T_{\text {react }}-$ $T_{i n i}$ in air supply case is higher than that in $\mathrm{O}_{2}$ case, resulting that the dehydration of PEM is afraid. In addition, the power generation performance in air supply case is worse than that in $\mathrm{O}_{2}$ supply case according to Table 3. Consequently, it is necessary to introduce the procedure of cooling and hydrating PEM under high temperature operation. For instance, it can be proposed that the water discharged from the outlet of the cell reuses in the cell by recirculation pipe line. In addition, the water transfer from the cathode to the anode or the reverse by controlling the difference of relative humidity of supply gas between the cathode and the anode might be also available. It is promising that the temperature elevation on reaction surface is prevented by the improvement of power generation performance with the additional water management system providing the effective energy conversion to electricity.

\section{Conclusions}

The temperature distribution on reaction surface was calculated by the 1D multi-plate heat transfer model proposed by this study under high temperature operation such as $90{ }^{\circ} \mathrm{C}$ condition. In addition, the effects of $T_{i n i}$, flow rate, relative humidity and type of supply gas on the temperature distribution on reaction surface have been also investigated. From the investigation of this study, the following conclusions have been obtained: 
(1) In the case of $\mathrm{O}_{2}$ supply condition, $T_{\text {react }}-T_{i n i}$ at the segments from $\mathrm{Q}$ to $\mathrm{T}$ decreases with the increasing of $T_{i n i}$ irrespective of relative humidity of supply gas. The PEM is dehydrated with gas flowing through gas channel, especially near the outlet of cell, which proceeds more at higher $T_{i n i}$, resulting that the temperature drops near the outlet due to degradation of electrochemical reaction performance. Regarding the segments except near the outlet, the effect of relative humidity of supply gas on the temperature distribution on reaction surface is confirmed. The difference of $T_{\text {react }}-T_{\text {ini }}$ among various $T_{\text {ini }}$ is small for $80 \% \mathrm{RH}$ and $60 \% \mathrm{RH}$, while $T_{\text {react }}-T_{\text {ini }}$ increases with increasing $T_{i n i}$ for $40 \% \mathrm{RH}$. This difference is brought about by the degradation of power generation performance due to dehydration of PEM.

(2) According to the comparison of temperature distribution on reaction surface between $\mathrm{O}_{2}$ and air supply cases, $T_{\text {react }}-T_{\text {ini }}$ in air supply case is higher than that in $\mathrm{O}_{2}$ supply case irrespective of $T_{i n i}$ and flow rate of supply gas since $H_{\text {react }}$ in air supply case is higher than that in $\mathrm{O}_{2}$ supply case due to poor power generation performance. It is observed that $T_{\text {react }}-T_{\text {ini }}$ at the segments from $\mathrm{Q}$ to $\mathrm{T}$ does not decrease in air supply case, while it decreases in $\mathrm{O}_{2}$ supply case. Since the reaction surface is cooled by the excess gas, the temperature drops caused by dehydration of PEM due to the accumulation of heat generated by power generation near the outlet of cell is not occurred.

(3) The temperature distribution on reaction surface in $\mathrm{O}_{2}$ supply case is wider with the increasing of $T_{i n i}$ as well as the decreasing of relative humidity of supply gas, though that in air supply case is relatively even. In addition, $T_{\text {react }}-T_{i n i}$ in air supply case is higher than that in $\mathrm{O}_{2}$ case.

(4) The additional water management system is necessary to obtain the good power generation performance of PEFC under high temperature operation.

\section{Acknowledgments}

This work was supported by Mie prefecture industrial research institute. The authors acknowledge its great contribution.

\section{References}

[1] Weber, A. Z., Darling, R. M., and Newman, J. 2004. "Modeling Two-Phase Behavior in PEFCs." Journal of Electrochemical Society 151 (10): A1715-27.

[2] Wang, M., Guo, H., and Ma, C. 2006. "Temperature Distribution on the MEA Surface of a PEMFC with Serpentine Channel Flow Bed." Journal of Power Sources 157 (1): 181-7.

[3] Ito, K. 2008. "Temperature Distribution Measurement in Through-Plane Direction for PEFC." Japan Society of Mechanical Engineers 111 (1079): 42-4.

[4] Tsuji, K. 2008. "Domestic Fuel Cell Co-generation System Entering Real Commercial Stage." Hydrogen Energy System 33 (3): 93-6.

[5] Zhang, G., Shen, S., Guo, L., and Liu, H. 2012. "Dynamic Characteristics of Local Current Densities and Temperatures in Proton Exchange Membrane Fuel Cells during Reactant Starvations." International Journal Hydrogen Energy 37 (2): 1884-92.

[6] Lee, C. Y., Fan, W. Y., and Chang, C. P. 2011. "A Novel Method for In-situ Monitoring of Local Voltage, Temperature and Humidity Distributions in Fuel Cell Using Flexible Multi-functional Micro Sensors." Sensors 11 (2): 1418-32

[7] Nishimura, A., Shibuya, K., Morimoto, A., Tanaka, S., Hirota, M., Nakamura, Y., Kojima, M., Narita, M., and $\mathrm{Hu}$, E. 2012. "Dominant Factor and Mechanism of Coupling Phenomena in Single Cell of Polymer Electrolyte Fuel Cell.” Applied Energy 90 (1): 73-9.

[8] Nishimura, A., Iio, K., Baba, M., Yamauchi, T., Hirota, M., and $\mathrm{Hu}$, E. 2014. "Modeling of Heat Transfer in Single Cell of Polymer Electrolyte Fuel Cell by Means of Temperature Data Measured by Thermograph." Journal of Chemical Engineering of Japan 47 (7): 521-9.

[9] Nishimura, A., Fukuoka, T., Baba, M., Hirota, M., and $\mathrm{Hu}$, E. 2015. "Clarification on Temperature Distribution in Single Cell of Polymer Electrolyte Fuel Cell under Different Operation Conditions by Means of 1D Multi-plate Heat-Transfer Model." Journal of Chemical Engineering of Japan 48 (10): 862-71.

[10] Khandelwal, M., and Mench, M. M. 2006. "Direct Measurement of Through-Plane Thermal Conductivity and Contact Resistance in Fuel Cell Materials." Journal of Power Sources 161 (2): 1106-15. 
[11] Kawase, M., Inagaki, T., Kawashima, S., and Miura, K. 2009. "Effective Thermal Conductivity of Gas Diffusion Layer in Through-Plane Direction." ECS Transactions 25 (1): 1529-37.

[12] Jung, C. Y., Shim, H. S., Koo, S. M., Lee, S. H., and Yi, S. C. 2012. "Investigation of the Temperature Distribution in Proton Exchange Membrane Fuel Cell." Applied Energy 93 (May): 733-41.

[13] NEDO (New Energy and Industry Technology Development Organization) Department of Fuel Cell and Hydrogen Technology. 2010. "Road Map 2010 of NEDO Fuel Cell and Hydrogen Technology Development." Accessed June 6, 2016. http://www.nedo.go.jp/content/100642949.pdf.

[14] Li, Q., He, R., Jensen, J. O., and Bjerrum, N. J. 2003. "Approaches and Recent Development Polymer Electrolyte Membrane for Fuel Cells Operating above $100{ }^{\circ}$ C." Chemical of Materials 15 (26): 4896-915.

[15] Hwang, S. S., Han, S. S., Lee, P. H., and Park, B. I. 2010. "Transient Performance Behavior of Proton Exchange Membrane Fuel Cell by Configuration of Membrane and
Gas Diffusion Layer." Journal of Thermal Science and Technology 5 (1): 165-77.

[16] Wu, H., Berg, P., and Li, X. 2010. "Steady and Unsteady 3D Non-isothermal Modeling of PEM Fuel Cells with the Effect of Non-equilibrium Phase Transfer." Applied Energy 87 (9): 2778-84.

[17] The Japan Society of Mechanical Engineers. 1993. JSME Heat Transfer Handbook. Tokyo: Maruzen.

[18] Oshima, A., Nishimura, A., Morimoto, A., Tanaka, S., Hirota, M., and Narita, M. 2010. "Theoretical Investigation on Influence of Inflow Gas Condition and Gas Channel Structure of Separator on Mass and Temperature Distribution in Single Cell of Polymer Electrolyte Fuel Cell." In Proceedings of the Mechanical Engineering Congress, 203-4.

[19] Zhang, J., Kramer, D., Shimoi, R., Ono, Y., Lehmann, E., Wokaun, A., Shinohara, K., and Sherer, G. G. 2006. "In situ Diagnostic of Two-Phase Flow Phenomena in Polymer Electrolyte Fuel Cells by Neutron Imaging, Part B. Material Variations." Electrochimical Acta 51 (13): 2715-27. 